\title{
11ß-Hydroxysteroid Dehydrogenase in Cultured Hippocampal Cells Reactivates Inert 11-Dehydrocorticosterone, Potentiating Neurotoxicity
}

\author{
Vidya Rajan, Christopher R. W. Edwards, and Jonathan R. Seckl \\ Edinburgh University, Department of Medicine, Western General Hospital, Edinburgh EH4 2XU, United Kingdom
}

$11 \beta$-Hydroxysteroid dehydrogenase $(11 \beta-H S D)$ catalyzes the conversion of the glucocorticoid corticosterone (cortisol in humans) to inert 11-dehydrocorticosterone (cortisone). 11 $\beta$-HSD activity is present in the hippocampus, where it is induced by glucocorticoids and stress in vivo, prompting suggestions that the enzyme may attenuate the deleterious effects of chronic glucocorticoid excess on neuronal function and survival. Two isoforms exist: $11 \beta$-HSD1, a bidirectional NADPH-dependent enzyme, and $11 \beta-H S D 2$, an $\mathrm{NAD}^{+}$-dependent exclusive $11 \beta$ dehydrogenase (corticosterone-inactivating enzyme). In this study, $11 \beta$-HSD1 activity and mRNA synthesis were demonstrated in primary fetal hippocampal cell cultures. Unexpectedly, the reaction direction in intact hippocampal cells was $11 \beta$-reduction (reactivation of inert 11-dehydrocorticosterone), although homogenization revealed that the enzyme was capable of $11 \beta$-dehydrogenation when removed from its normal cellular context. Dexamethasone $\left(10^{-7} \mathrm{M}\right)$ increased $11 \beta$-HSD activity in homogenates of hippocampal cultures $(102 \%$ increase). In intact hippocampal cells, dexamethasone induced $11 \beta$ reductase, not dehydrogenase. To determine the functional relevance of hippocampal 11 $\beta$-reductase, glucocorticoid potentiation of kainic acid neurotoxicity was examined. Pretreatment of hippocampal cells with corticosterone reduced survival on kainate exposure. Hippocampal cell $11 \beta$ HSD activity was potently inhibited by carbenoxolone. Carbenoxolone had no effect on cell survival after kainate alone and did not alter the effect of corticosterone. 11-Dehydrocorticosterone also potentiated kainate neurotoxicity; this effect was lost, however, if $11 \beta$-HSD was inhibited with carbenoxolone. Thus, hippocampal $11 \beta$-HSD seems to be a functional $11 \beta$-reductase in intact cells. Measures to attenuate hippocampal 11 $\beta$-reductase may reduce neuronal vulnerability to glucocorticoid toxicity.

Key words: NADPH; dexamethasone; glucocorticoids; carbenoxolone; corticosterone; kainic acid
$11 \beta$-Hydroxysteroid dehydrogenase ( $11 \beta$-HSD) catalyzes the conversion of physiological glucocorticoids (corticosterone, cortisol) to inert 11-keto derivatives (11-dehydrocorticosterone, cortisone) (Monder and White, 1993). In vivo, 11 $\beta$-HSD ensures selective access of aldosterone over corticosterone to mineralocorticoid receptors (MRs) in the distal nephron (Edwards et al., 1988; Funder et al., 1988); MRs are otherwise nonselective and bind corticosterone with similar affinity to aldosterone in vitro (Arriza et al., 1987, 1988). When $11 \beta$-HSD is congenitally absent or inhibited by licorice (or its derivative carbenoxolone), glucocorticoids illicitly occupy renal MRs, causing sodium retention and hypertension (Stewart et al., 1987, 1988, 1990)

Glucocorticoids, which are released from the adrenal cortex in response to circadian or stress-induced activation of the hypothalamic-pituitary-adrenal axis, subserve many roles in homeostasis and the response to stress. The brain is a key target for glucocorticoid action, which is mediated via both MRs and lower affinity glucocorticoid receptors (McEwen et al., 1986a; de Kloet, 1991; Seckl and Olsson, 1995). The hippocampus expresses a higher density of MRs than does the kidney, but these sites are

\footnotetext{
Received Aug. 1, 1995; revised Sept. 7, 1995; accepted Sept. 13, 1995.
}

This work was supported by a Wellcome Senior Clinical Research Fellowship (J.R.S.), a Wellcome Trust program grant (C.R.W.E., J.R.S.), and a travel grant from the Scottish Hospital Endowments Research Trust (V.R.). We are grateful to Dr. Roger Brown for helpful discussions and to Ms. Josie Diorio for excellent technical assistance with hippocampal cultures.

Correspondence should be addressed to Dr. J. R. Seckl, Molecular Endocrinology Laboratory, University of Edinburgh, Department of Medicine, Western General Hospital, Edinburgh EH4 2XU, UK.

Copyright $\mathbb{C}$ 1995 Society for Neuroscience $0270-6474 / 95 / 160065-06 \$ 05.00 / 0$ occupied by corticosterone in vivo (de Kloet et al., 1975; Reul and de Kloet, 1985; McEwen et al., 1986a; de Kloet, 1991), suggesting that $11 \beta$-HSD is absent. However, several recent studies have demonstrated $11 \beta$-HSD activity, immunoreactivity, and mRNA expression in hippocampal cells (neurons) (Moisan et al., 1990; Lakshmi et al., 1991; Sakai et al., 1992), raising the possibility of an aldosterone-selective subset of hippocampal MRs (Moisan et al., 1990). Indeed, some data suggest that a proportion of hippocampal aldosterone binding is not readily displaced by corticosterone (McEwen et al., 1986b) and that not all functions of aldosterone and corticosterone in the hippocampus are identical (de Kloet et al., 1983). Administration of 11 $\beta$-HSD inhibitors alters functional activity in the hippocampus in vivo (Seckl et al., 1991), although the mechanisms underpinning this effect are obscure. Hippocampal $11 \beta-H S D$ is induced by chronic glucocorticoid excess or stress (Low et al., 1994b). Because chronic glucocorticoid excess exerts well documented deleterious actions on hippocampal cell function and survival (Landfield et al., 1978; Sapolsky et al., 1985, 1986; Sapolsky, 1992), it has been postulated that such induction of $11 \beta$-HSD is protective (Monder, 1991; Low et al., 1994b; Seckl and Olsson, 1995). Nevertheless, the presence of $11 \beta$-HSD activity in the hippocampus contradicts a majority of data, which indicate nonselective MRs at this site.

Recently, it has become apparent that there are at least two distinct $11 \beta$-HSD isoforms (Seckl, 1993). Target organs for aldosterone and the placenta express a high-affinity, $\mathrm{NAD}^{+}$-dependent enzyme (11 $\beta$-HSD2), which is an exclusive $11 \beta$-dehydrogenase (corticosterone inactivating enzyme) (Brown et al., 1993; Albiston et al., 1994). In contrast, the liver-derived isoform (11 $\beta$-HSD1) is 
a lower-affinity, $\mathrm{NADP}^{+} / \mathrm{NADPH}$-dependent enzyme (Lakshmi and Monder, 1988; Agarwal et al., 1989). Expression of $11 \beta$-HSD1 cDNA in a range of cell lines encodes either a bidirectional enzyme (Agarwal et al., 1989) or a predominant $11 \beta$-reductase (Duperrex et al., 1993; Low et al., 1994a). $11 \beta$-Reductase activity, best observed in intact cells, activates 11-dehydrocorticosterone to alter target gene transcription and differentiated cell function (Duperrex et al., 1993; Low et al., 1994b). In homogenates of hippocampus, both dehydrogenation and reduction occur (Lakshmi et al., 1991), but the reaction direction in intact cells is unknown. We therefore have examined $11 \beta$-HSD activity and its function in primary cultures of fetal hippocampal cells.

\section{MATERIALS AND METHODS}

Cell culture media were obtained from Gibco (Paisley, UK); corticosterone (B), 11-dehydrocorticosterone (A), poly-D-lysine, insulin, apo-transferrin, putrescine, sodium selenite, and progesterone were obtained from Sigma (Poole, UK). Tissue culture plastics were from Costar UK Ltd (High Wycombe, Bucks, UK). $\left[{ }^{3} \mathrm{H}\right]-1,2,6,7$-Corticosterone $\left(\left[{ }^{3} \mathrm{H}\right] \mathrm{B} ; \sim 72\right.$ $\mathrm{Ci} / \mathrm{mmol}$ ) was obtained from Amersham International (Aylesbury, Bucks, UK). $\left[{ }^{3} \mathrm{H}\right] 11-$ Dehydrocorticosterone $\left(\left[{ }^{3} \mathrm{H}\right] \mathrm{A}\right)$ was prepared by incubating $\left[{ }^{3} \mathrm{H}\right] \mathrm{B}$ with human placental extract, a concentrated source of $11 \beta$ dehydrogenase (11 $\beta$-HSD2), as described previously (Low et al., 1994a). Purity was typically $>99 \%$, monitored on HPLC.

Primary hippocampal neuronal culture. The cell cultures were prepared according to a method derived from Mitchell et al. (1990). The medium (pH 7.3) contained DMEM with Glutamax-I $(0.086 \%), 10 \%$ fetal bovine serum (FBS) or donor horse serum (DHS), $15 \mathrm{mM} \mathrm{HEPES,} 100 \mathrm{IU} / \mathrm{m}$ penicillin, and $100 \mu \mathrm{g} / \mathrm{ml}$ streptomycin and glucose increased to $0.2 \%$. Day 18 fetuses were removed by laparatomy, and the hippocampi were dissected into HBSS containing $15 \mathrm{~mm}$ HEPES, $\mathrm{pH}$ 7.4. The cells wcrc incubated in trypsin-EDTA for $20 \mathrm{~min}$, washed, and mechanically dissociated by trituration. Cells were seeded at a density of $0.8-1.0 \times 10^{6}$ cells $/ \mathrm{ml}$ of medium and plated on $35 \mathrm{~mm}$ Petri dishes previously coated with $0.025 \mathrm{mg} / \mathrm{ml}$ poly-D-lysine. The cells were cultured in a watersaturated atmosphere at $37^{\circ} \mathrm{C}, 10 \% \mathrm{CO}_{2}$, for $3 \mathrm{~d}$ in the presence of serum, and then changed to defined (serum-free) medium (DMEM-F12 containing Glutamax-I, $10 \mu \mathrm{g} / \mathrm{ml}$ insulin, $100 \mu \mathrm{g} / \mathrm{ml}$ transferrin, $60 \mu \mathrm{M}$ putrescine, $20 \mathrm{~nm}$ sodium selenite, $20 \mathrm{nM}$ progesterone, $100 \mathrm{IU} / \mathrm{ml}$ penicillin, and 100 $\mu \mathrm{g} / \mathrm{ml}$ streptomycin). The cells were maintained in this medium for $5 \mathrm{~d}$ with one-third of the medium changed every $3 \mathrm{~d}$ until experimentation. Under these conditions, the cultures contained $60-80 \%$ neurons with glia forming the remainder, as determined by immunostaining of specimen cultures with antisera to glial fibrillary axial protein and neuron-specific cnolasc.

$11 \beta$-HSD activity. $11 \beta$-Reductase and $11 \beta$-dehydrogenase activity were determined in intact primary hippocampal cells by the addition of $25 \mathrm{nM}$ $\left[{ }^{3} \mathrm{H}\right] \mathrm{A}$ or $\left[{ }^{3} \mathrm{H}\right] \mathrm{B}$ to the medium, as described previously (Low et al., 1994a). Aliquots of the culture medium were removed at intervals over 24 hr and put into ethyl acetate; the steroids were extracted, dried under $\mathrm{N}_{2}$, and suspended in $100 \mathrm{ml}$ of ethanol containing $2.5 \mathrm{mg} / \mathrm{ml}$ cold $A$ and $B$. Steroids were separated by thin-layer chromatography (TLC) in chloroform $/ 95 \%$ ethanol $(92: 8)$, and bands were visualized under ultraviolet light and scraped into scintillation vials containing $3 \mathrm{ml}$ of liquid scintillant (Cocktail T, BDH, Lutterworth, UK). The radioactivity in each fraction was determined, and enzyme activity was expressed as the percentage conversion to reaction product (Low et al., 1994a). Blanks, ${ }^{3} \mathrm{H}$-labeled steroids incubated in medium on dishes without cells and extracted as above, were subtracted.

$11 \beta$-Reductase and $11 \beta$-dehydrogenase activity also were determined in homogenates of cultured hippocampal cells, broadly as described previously (Moisan et al., 1990; Low et al., 1994a). Cells were washed with PBS and homogenized in Buffer $C[20 \mathrm{~mm}$ tricine, $1.07 \mathrm{~mm}$ $\left(\mathrm{MgCO}_{3}\right)_{4} \cdot \mathrm{Mg}(\mathrm{OH})_{2} \cdot 5 \mathrm{H}_{2} \mathrm{O}, 2.67 \mathrm{~mm} \mathrm{MgSO}{ }_{4}, 0.1 \mathrm{~mm}$ EDTA, $33.3 \mathrm{~mm}$ DTT, and $0.2 \mathrm{mg} / \mathrm{ml}$ coenzyme A] containing $0.1 \%$ Triton X-100. Protein was measured by Bradford's method (Bio-Rad protein assay kit, Bio-Rad, Hemel Hempstead, UK). Preliminary studies established conditions such that the amount of protein added was within the linear portion of the relationship between protein concentration and percentage substrate conversion. Thus, an aliquot of hippocampal cell homogenate (typically $64 \mu \mathrm{g}$ protein $/ \mathrm{ml}$ ) was incubated at $37^{\circ} \mathrm{C}$ for $60 \mathrm{~min}$ with $10 \mathrm{nM}\left[{ }^{3} \mathrm{H}\right] \mathrm{B}$

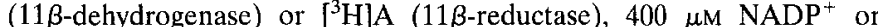
NADPH, and PBS to a total volume of $50 \mu \mathrm{l}$. Steroids were extracted and separated by TLC, and enzyme activity was calculated. Blanks were subtracted.

$11 \beta-I I S D m R N A$ analysis. Expression of $11 \beta$-HSD1 and $11 \beta$-IISD2 mRNA was determined by PCR. In brief, total RNA was extracted from cell homogenates with guanidinium thiocyanate (Chomczynski and Sacchi, 1987). One microgram of RNA was subjected to reverse transcription in a total volume of $20 \mu \mathrm{l}$ using the Promega Reverse transcription kit (Promega, Southampton, UK). A $2 \mu$ aliquot of the reverse transcription reaction was used in the PCR reaction after denaturation at $96^{\circ} \mathrm{C}$ for 10 min. The PCR mix contained $1.5 \mathrm{~mm} \mathrm{MgCl}, 40 \mu \mathrm{M}$ dNTPs, 20 pmol of each primer, and $2.5 \mathrm{U}$ of $\mathrm{Ta}$ DNA polymerase in a final volume of 50 $\mu l$. The primer pairs for $11 \beta$-HSD 1 were $869 \mathrm{P}$ (5'-AAAGCTTGTCACA TGGGGCCAGCAAA-3'), corresponding to nucleotides $178-207$ of rat $11 \beta$-HSD1 cDNA, and 868P (5'-AGGATCCAG/AAGCAAACTTGCTTGCA-3'), complementary to nucleotides $648-628$ of rat $11 \beta-H S D 1$ cDNA. The primer pairs for $11 \beta$-HSD2 were P2520 (5'-CAATGCTGGCCTCAACATGGT-3'), corresponding to nucleotides 624-644 of the rat 11 $\beta$-HSD2 cDNA, and P2521 (5'-GGTCCTGGGTTGTGTCATGAA-3'), complementary to nucleotides $1297-1277$ of the rat $11 \beta$-HSD2 cDNA sequence (Zhou et al., 1995). Both sets of primers span intron sequences to distinguish DNA products $(>4 \mathrm{~kb}$ for $11 \beta$-HSD1, $\sim 0.93 \mathrm{~kb}$ for $11 \beta$-HSD2) from mRNA products $(0.43 \mathrm{~kb}$ for $11 \beta$-HSD1, $0.63 \mathrm{~kb}$ for $11 \beta$-HSD2). The PCR conditions were 30 cycles of $96^{\circ} \mathrm{C}$ for $30 \mathrm{sec}, 50^{\circ} \mathrm{C}$ for $45 \mathrm{sec}$, and $72^{\circ} \mathrm{C}$ for $90 \mathrm{sec}$, followed by extension at $72^{\circ} \mathrm{C}$ for $10 \mathrm{~min}$.

Modulation of $11 \beta-H S D$ activity in primary hippocampal cells. To determine whether $11 \beta$-HSD activity in intact hippocampal cells was inhibited by licorice derivatives, cultures were pretreated with carbenoxolone $\left(10^{-6} \mathrm{M}\right)$ for $24 \mathrm{hr}$, and enzyme activity in $11 \beta$-reductase and $11 \beta$-dehydrogenase directions was estimated, as above. Glucocorticoid effects on enzyme activity were determined by preincubation of cultured hippocampal cells with dexamethasone $\left(10^{-7} \mathrm{M}\right)$ for $72 \mathrm{hr}$ before enzyme measurement in intact cells after $8 \mathrm{hr}$ incubation with ${ }^{3} \mathrm{H}$-labeled steroids (a period chosen to reflect submaximal $11 \beta$-reductase and detectable $11 \beta$-dehydrogenase activities).

Effects of $11 \beta-H S D$ on hippocampal cell vulnerability to kainate toxicity. To determine the functional relevance of $11 \beta$-HSD activity in primary cultures of hippocampal cells, the effects of corticosterone and 11-dehydrocorticosterone in the presence or absence of carbenoxolone on cell survival in response to kainic acid stimulation were determined, as described previously (Sapolsky, 1986; Packan and Sapolsky, 1990). In brief, cells were cultured as described above, but in the presence of $2 \%$ FBS to improve cell survival in the presence of kainic acid. This did not alter the predominant $11 \beta$-reduction in intact hippocampal cells or affect enzyme activity levels: corticosteroid levels are $<10^{-10} \mathrm{M}$ in FBS (S.C. Low and J. R. Seckl, unpublished observations.) Plates of cells were pre-exposed to 11-dehydrocorticosterone $\left(10^{-5} \mathrm{M}\right)$ or corticosterone $\left(10^{-5} \mathrm{M}\right)$ in the presence or absence of carbenoxolone $\left(10^{-6} \mathrm{M}\right)$ for $24 \mathrm{hr}$ Controls included cultures exposed to carbenoxolone alone and cultures to which nothing was added. All cells then received kainic acid $\left(10^{-5} \mathrm{M}\right)$ After $48 \mathrm{hr}$, cells were washed in PBS, scraped into $1.2 \mathrm{ml}$ of potassium phosphate buffer, $\mathrm{pH} 7.5$, containing $0.5 \%$ Triton $\mathrm{X}-100$, and lactate dehydrogenase activity was determined, using a kit (Sigma) according to the instructions of the manufacturer, as a measure of cell survival (Sapolsky, 1986; Packan and Sapolsky, 1990). Control plates that were not exposed to steroid or carbenoxolone were taken to represent $100 \%$ survival, and blanks represented $0 \%$ survival.

Statistics. Three to eight plates of cells were used for each data point. Data were assessed by ANOVA followed by Newman-Keuls post hoc test or Student's $t$ tests, where appropriate. Significance was set at $p<0.05$. Values are mean \pm SEM.

\section{RESULTS}

\section{$11 \beta-H S D$ in cultured hippocampal cells}

Primary fetal hippocampal cell cultures showed clear $11 \beta$-HSD activity in cell homogenates. $\mathrm{NADP}^{+}$-dependent $11 \beta$-dehydrogenase and NADPH-dependent $11 \beta$-reductase activity was clearly detectable after $1 \mathrm{hr}$ incubation (Fig. 1). $\mathrm{NAD}^{+}$-dependent activity was only just above basal enzyme activity (with no added cosubstrate; Fig. 1). PCR analysis showed clear expression of $11 \beta$-HSD1 mRNA, but no detectable expression of $11 \beta$-HSD2 mRNA (Fig. 2). Northern analysis showed only one hybridizing 


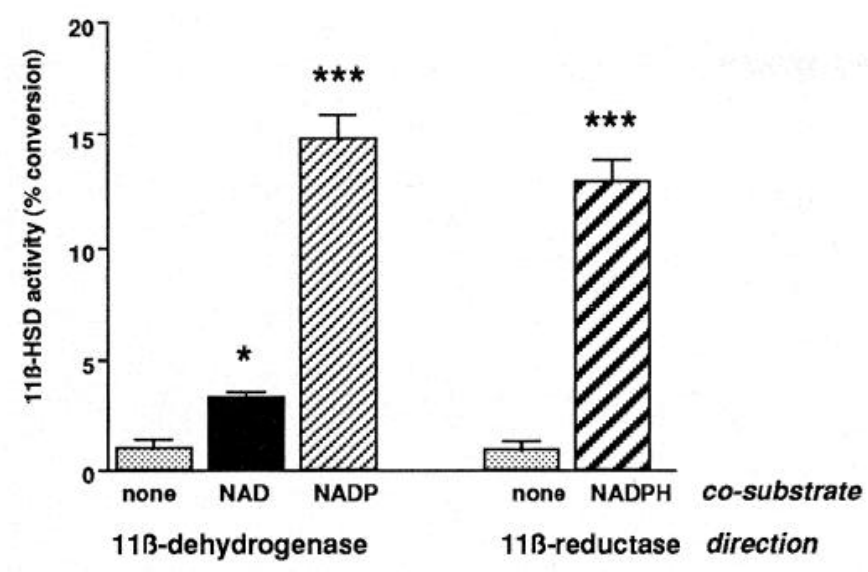

Figure 1. Cosubstrate dependence and reaction direction of $11 \beta$-HSD in homogenates of cultured primary hippocampal cells. Cosubstrates were added at $400 \mu \mathrm{M}$. Note the predominant $\mathrm{NADP}^{+} / \mathrm{NADPH}$-dependent reaction, typical of $11 \beta$-HSD1, and the obvious bidirectional activity in homogenates. ${ }^{*} p<0.05$ and ${ }^{* * *} p<0.0001$ compared with the appropriate control without exogenous cosubstrate.

species of $11 \beta$-HSD1 transcript, identical in size to the transcript in rat liver (data not shown), confirming previous studies of $11 \beta$-HSD1 transcripts in adult and fetal rat hippocampus in vivo (Moisan et al., 1990, 1992; Low et al., 1994b).

In contrast, predominant $11 \beta$-reduction was found (Fig. 3) in intact hippocampal cells, with clearly detectable conversion of inert 11-dehydrocorticosterone to corticosterone within $30 \mathrm{~min}$ of addition of steroid, and $78 \%$ conversion after $24 \mathrm{hr}$. This represented plateau activity because no further conversion occurred after $48 \mathrm{hr}$ incubation with $\left[{ }^{3} \mathrm{H}\right] \mathrm{A}$ (data not shown). $11 \beta$-Dehydrogenase activity only became detectable after $8 \mathrm{hr}$ incubation with $\left[{ }^{3} \mathrm{H}\right] \mathrm{B}(4 \pm 1 \%$ conversion $)$ and reached a mere $6.5 \pm 1 \%$ conversion at $24 \mathrm{hr}$ (Fig. 3). Pretreatment of cultures with the $11 \beta$-HSD inhibitor carbenoxolone $\left(10^{-6} \mathrm{M}\right)$ almost completely inhibited enzyme activity in intact hippocampal cells in

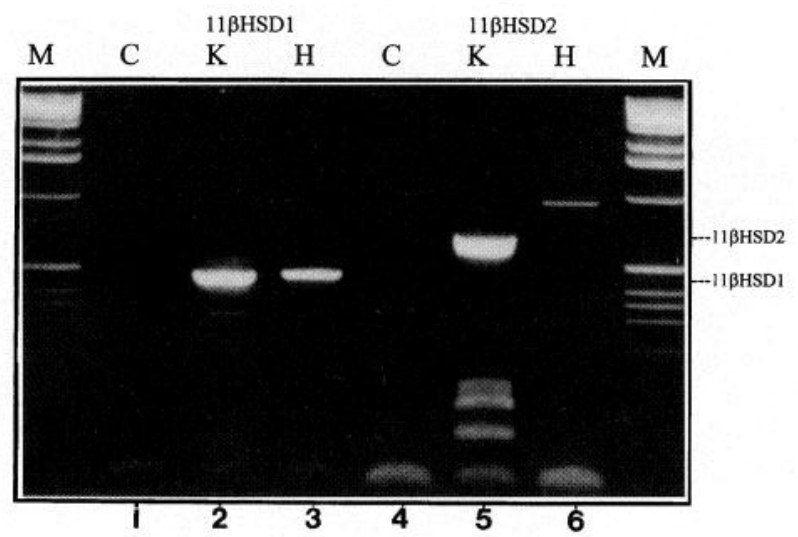

Figure 2. Presence of $11 \beta$-HSD1 mRNA in cultured primary hippocampal cells. Total RNA from 11-d-old cultures was subjected to reverse transcription followed by PCR using primers specific for $11 \beta$-HSD 1 and $11 \beta$-HSD2. Lane 1, Negative control $(C)$; lane 2, positive control kidney RNA $(K)$; lane 3, hippocampal cell culture RNA $(H)$; lane 4, negative control $(C)$; lane 5, positive control kidney RNA $(K)$; and lane 6 , hippocampal cell culture RNA $(H) . M$ indicates marker lanes. Reactions in lanes 1, 2, and 3 contained $11 \beta$-HSD1-specific primers, and lanes 4,5 , and 6 contained $11 \beta$-HSD2-specific primers. Note the presence of a band in lane 3 corresponding to hippocampal $11 \beta$-HSD1. The band in lanes 5 and 6 migrating at $\sim 0.9 \mathrm{~kb}$ corresponds to DNA-generated PCR product (see Results).

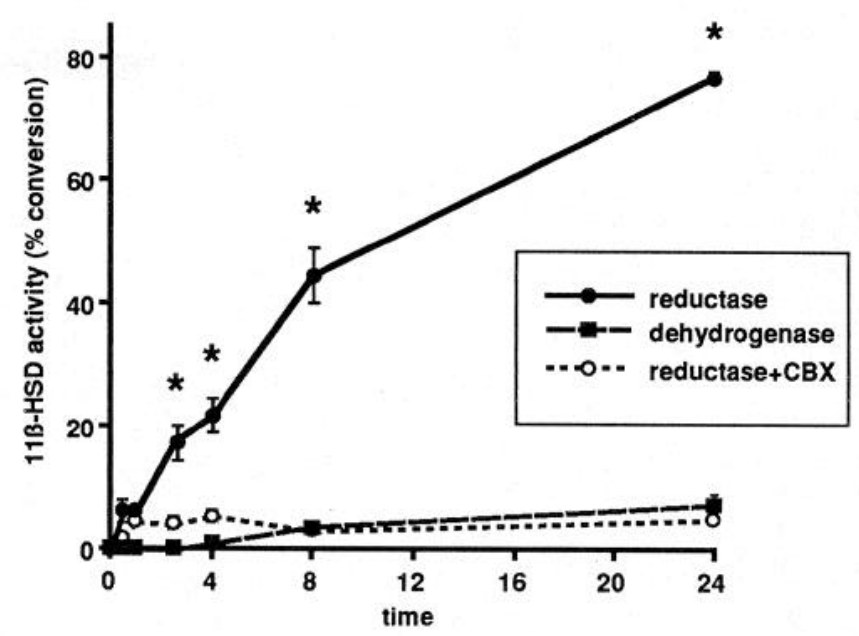

Figure 3. Reaction direction of $11 \beta$-HSD in intact primary hippocampal cells in vitro. $\left[{ }^{3} \mathrm{H}\right]$ Corticosterone or $\left[{ }^{3} \mathrm{H}\right] 11$-dehydrocorticosterone was added to the culture medium, and $\left[{ }^{3} \mathrm{H}\right]$ corticosteroids in the medium were assayed at intervals. Note the predominant $11 \beta$-reduction in intact hippocampal cells. Carbenoxolone (CBX; $\left.10^{-6} \mathrm{M}\right)$ inhibits the reaction. ${ }^{*} p<$ 0.01 for $11 \beta$-reductase activity compared with either carbenoxolone-inhibited $11 \beta$ reductase or $11 \beta$-dehydrogenase at the same time point.

both $11 \beta$-reductase (Fig. 3) and $11 \beta$-dehydrogenase (data not shown) directions.

\section{Glucocorticoid modulation of hippocampal cell $11 \beta$-HSD activity}

Treatment of primary hippocampal cell cultures with dexamethasone $\left(10^{-7} \mathrm{M}\right)$ for $72 \mathrm{hr}$ increased $11 \beta$-HSD activity in cell homogenates (102\% increase in $11 \beta$-dehydrogenase, $72 \%$ increase in $11 \beta$-reductase). In intact cells, this was exclusively an increase in $11 \beta$-reductase activity (by $43 \%$ ), with no alteration in dehydrogenation detected (Fig. 4).

\section{Effect of $11 \beta$-HSD on hippocampal cell survival in the presence of kainic acid}

Preliminary experiments showed that both $10^{-7}$ and $10^{-5} \mathrm{M}$ corticosterone potentiated kainic acid-mediated neurotoxicity, but this was considerably more apparent with the higher dose (data not shown). We therefore used the $10^{-5} \mathrm{M}$ dose to study the effect of $11 \beta$-HSD in these cells. In the presence of corticosterone, kainic acid exerted significantly greater neurotoxicity than did kainic acid alone (Fig. 5), confirming previous studies (Sapolsky, 1986; Packan and Sapolsky, 1990). Carbenoxolone $\left(10^{-6} \mathrm{M}\right) \mathrm{did}$ not alter the effect of corticosterone $\left(10^{-5} \mathrm{M}\right)$ on hippocampal cell loss in the presence of corticosterone, nor did $10^{-6} \mathrm{M}$ carbenoxolone alone affect cell loss in the face of kainic acid stimulation (Fig. 5). 11-Dehydrocorticosterone $\left(10^{-5} \mathrm{M}\right)$ also potentiated kainic acid neurotoxicity and was at least as potent in this action as corticosterone (Fig. 5). However, inhibition of $11 \beta$-HSD with carbenoxolone $\left(10^{-6} \mathrm{M}\right)$ abolished the cytotoxic potentiating effects of 11-dehydrocorticosterone in hippocampal cultures.

\section{DISCUSSION}

These studies clearly demonstrate $11 \beta$-HSD activity in primary hippocampal cell cultures. A majority of the cultured cells were neurons, and it seems likely that the activity, taken together with previous immunocytochemical and in situ hybridization data showing a predominant neuronal localization of $11 \beta$-HSD in several brain regions in vivo (Moisan et al., 1990; Sakai et al., 1992 ), reflects $11 \beta$-HSD largely in neurons in the fetal hippocam- 


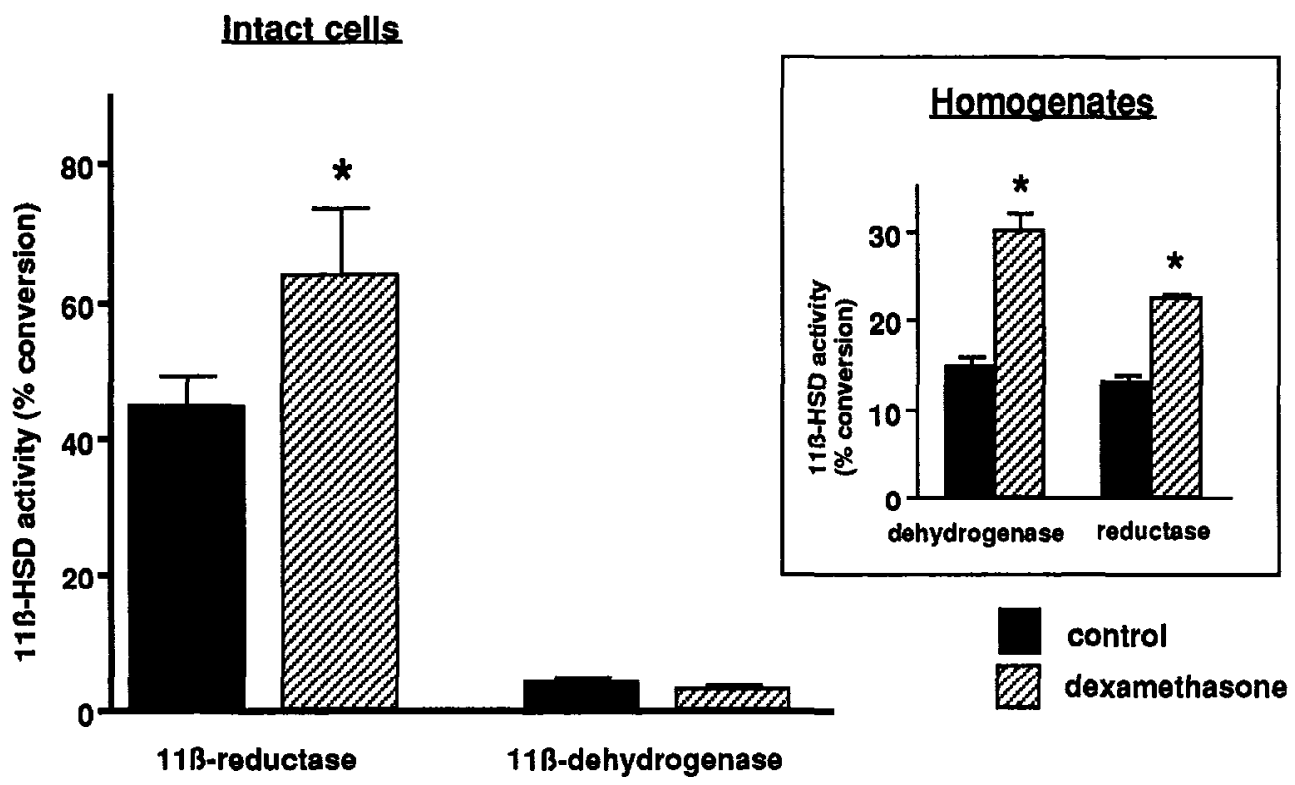

Figure 4. Effect of dexamethasone $\left(10^{-7} \mathrm{M}\right.$ for $\left.72 \mathrm{hr}\right)$ on $11 \beta$-HSD activity in intact primary hippocampal cells and cell homogenates (inset). Note that dexamethasone induces hippocampal cell $11 \beta-\mathrm{HSD}$ activity in vitro, but the reaction is $11 \beta$-reduction in intact cells. ${ }^{*} p<0.05$ compared with control.

pal cultures. $11 \beta$-HSD activity was detectable in culture for more than $8 \mathrm{~d}$, suggesting that it is stable under the conditions that were used. In intact hippocampal cells, $11 \beta$-reduction was clearly the predominant reaction direction. Dehydrogenation was barely detectable in intact hippocampal cells, and at the $8 \mathrm{hr}$ time point at which $11 \beta$-dehydrogenation became detectable and $11 \beta$-reduction had not reached plateau values, the ratio of reduction to dehydrogenation was $11.5: 1$. Few previous studies have addressed the reaction direction of $11 \beta$-HSD in brain in vivo. Those reported have used peripheral injection of radiolabeled glucocorticoids and have examined the concentrations of 11-hydroxy to 11-keto products in target tissues (Burton and Tufnell, 1967). Uptake into the brain is low using such approaches, and in any event the data are complicated by peripheral conversion of steroids before entry into the brain, which largely reflects the balance of $11 \beta$-reduction in the liver and $11 \beta$-dehydrogenation in the kidney. No studies have examined $11 \beta$-reduction in brain in vivo, and indeed it is difficult to envisage satisfactory experimental protocols to overcome peripheral interconversion of corticoids without their direct infusion into the central nervous system.

In contrast, in homogenates of hippocampal cells, $11 \beta$-dehydrogenase was readily detectable and indeed exceeded $11 \beta$-reductase activity. This confirms studies in homogenates of hippocampus in vivo, which show both dehydrogenation and reduction reactions (Lakshmi et al., 1991; Seckl et al., 1993). The basis for the discrepancy between predominant reduction in intact cells and dehydrogenation in homogenates of these cells is unclear but not unique to the hippocampus. Thus, transfection of COS7 cells with an expression plasmid encoding $11 \beta-H S D 1$ produces exclusively $11 \beta$-reductase activity in intact cells, but potent dehydrogenation is revealed when the transfected cells are homogenized (Low et al., 1994a). Reaction direction has been suggested to be determined by the glycosylation status of the enzyme or the tissue cosubstrate condition (Agarwal et al., 1990; Monder and White, 1993). Variations in glycosylation cannot explain near-exclusive reduction in intact hippocampal cells when dehydrogenation predominates immediatcly aftcr thcse cells are homogenized. Moreover, any variations in $\mathrm{NADP}^{+} / \mathrm{NADPH}$ ratios are unlikely to be sufficient to account for the dramatic change in reaction direction observed, and even gross changes in these ratios in intact cells have little effect on reaction direction of $11 \beta$-HSD1, at least in the liver (Jamieson et al., 1995). Thus, it seems more likely that the subcellular context of the enzyme determines the reaction direction, with homogenization disrupting this. Whether or not the reductase component is unstable in homogenates, it is clear from these data that dehydrogenation is revealed by cellular disruption, but it is at most a minor reaction in intact hippocampal cells and, by implication, in the hippocampus in vivo. The lack of $11 \beta$-dehydrogenation in intact hippocampal cell cultures also concurs with the nonselectivity of hippocampal MRs in vivo (de Kloet et al., 1975, 1991; Reul and de Kloet, 1985; McEwen et al., 1986a). Whether $11 \beta$-HSD2 (an exclusive dehydrogenase) is present in the hippocampus is still debatable. Northern analysis shows no expression of $11 \beta-\mathrm{HSD} 2 \mathrm{mRNA}$ in whole (human) brain

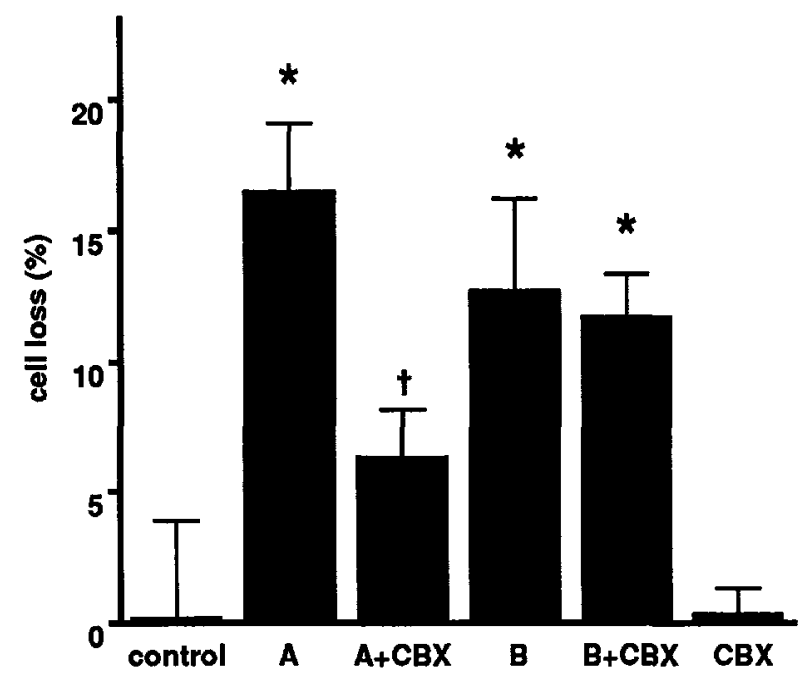

Figure 5. Effect of pretreatment with corticosterone $\left(B ; 10^{-5} \mathrm{M}\right)$ and 11-dehydrocorticosterone $\left(A ; 10^{-5} \mathrm{M}\right)$ with or without carbenoxolone $\left(C B X ; 10^{-6} \mathrm{M}\right)$ on hippocampal cell loss after exposure to kainic acid $\left(10^{-5} \mathrm{M}\right)$. Carbenoxolone alone has no effect on cells and does not alter the neurotoxic potentiation of corticosterone ( $B$ vs $B+C B X$ ). However, 11-dehydrocorticosterone $(A)$ toxicity is prevented by carbenoxolone $(A$ vs $A+C B X)$, indicating that hippocampal cell $11 \beta$-HSD acts as a functional $11 \beta$-reductase in this model. ${ }^{*} p<0.05$ compared with control; ${ }^{\dagger} p<0.05$ compared with $A$ alone. 
(Albiston et al., 1994), and in situ hybridization studies have failed to find $11 \beta$-HSD2 mRNA in the adult rat hippocampus (Roland et al., 1995). In contrast, a recent PCR-based study showed $11 \beta$-HSD2 transcripts in adult hippocampus (Zhou et al., 1995). Using a similar PCR approach, however, we could not detect $11 \beta$-HSD 2 mRNA in primary hippocampal cell cultures and, importantly, found little $\mathrm{NAD}^{+}$-dependent bioactivity. Thus, hippocampal expression of this MR-protective $11 \beta$-HSD isoform is probably negligible, at least in adult and late fetal life.

Previous studies have shown that chronic glucocorticoid (dexamethasone) excess or stress increase $11 \beta$-HSD 1 mRNA expression and enzyme bioactivity (measured as dehydrogenation in homogenates) in the rat hippocampus (Low et al., 1994b). Because treatment of primary hippocampal cultures with dexamethasone increased $11 \beta$-HSD activity, it is probable that this effect of glucocorticoids is mediated directly on hippocampal neurons, and there is a putative glucocorticoid response element in the promoter of the rat 11 $\beta$-HSD1 gene (Moisan et al., 1992). Moreover, preliminary data from transfection experiments with plasmids in which $11 \beta$-HSD1 promoter DNA is fuscd to a reporter genc suggest that a functional glucocorticoid response element lies within 3700 base pairs of the transcription start site (K. E. Chapman, M. Voice, R. Wallace, V. Lyons, and J. R. Seckl, unpublished observations). Although it has been proposed that induction of $11 \beta$-HSD in the hippocampus may protect vulnerable neurons from the deleterious consequences of chronic glucocorticoid excess (Monder, 1991; Low et al., 1994b), the activity induced by dexamethasone was exclusively $11 \beta$-reductase, a finding incompatible with this notion. Thus, hippocampal $11 \beta-H S D$ may potentiate rather than attenuate the neurotoxic effects of chronic glucocorticoid overexposure.

To examine this further, the effects of enzyme inhibition in both reductase and dehydrogenase directions was determined by using carbenoxolone. Potentiation of kainic acid neurotoxicity with $10^{-7}$ and $10^{-5} \mathrm{M}$ corticosterone was found in primary hippocampal cell cultures, confirming previous studies (Sapolsky, 1986; Packan and Sapolsky, 1990). Although supraphysiological levels of steroids were used in vitro, physiological concentrations $\left(10^{-7} \mathrm{M}\right)$ are effective in potentiating kainic acid neurotoxicity in this system (Packan and Sapolsky, 1990; and these data), although the changes were small during the short time course used here. In vivo, corticosteroid effects take many days to become manifest (Sapolsky et al., 1985), and we have used higher concentrations to amplify effects in cell cultures. That the effect of corticosterone was unaltered by carbenoxolone in a dose that inhibited both reaction directions but had no direct effect on cell survival supports the relative lack of importance of $11 \beta$-dehydrogenation in these cells. 11-Dehydrocorticosterone, which has $10^{4}$-fold lower affinity for receptors than does corticosterone (Ulmann et al., 1975; Armanini et al., 1983), was at least as effective as corticosterone in potentiating kainic acid toxicity. The functionality of $11 \beta$-reductasc was clear, inasmuch as 11 -dehydrocorticosterone was ineffective when $11 \beta$-HSD was inhibited by carbenoxolone. These data support the predominant $11 \beta$-reductase action of hippocampal $11 \beta$-HSD.

The reasons for an enzyme regenerating active glucocorticoids in the hippocampus are obscure. Hippocampal cells are exquisitely sensitive to glucocorticoid concentrations, with granular neuronal dysfunction and possibly death in the dentate gyrus after adrenalectomy (Sloviter et al,, 1989; Gould et al., 1990) and pyramidal neuronal loss in the cornu ammonis with glucocorticoid excess (Landfield et al., 1978; Sapolsky et al., 1985, 1986;
Sapolsky, 1985, 1992; Landfield and Eldridge, 1991). In the rat, corticosterone levels are very low during the day but show a pronounced diurnal increase in the evening. The biological importance of this rhythm is unclear, but the maintenance of many constitutive cellular functions may require more than the minimal levels of circulating corticosterone that pertain during the majority of the day. Thus, local $11 \beta$-reduction may increase corticosterone levels in specific tissues and, hence, 11-dehydrocorticosterone may form a circulating reservoir of inert corticosteroid for cellspecific activation (the apparent absence of $11 \beta$-HSD2 in the hippocampus suggests that 11-dehydrocorticosterone comes from the periphery rather than from local cellular production). Certainly in humans, cortisone (the equivalent of 11-dehydrocorticosterone) shows near-constant levels throughout the $24 \mathrm{hr}$ period. Moreover, plasma concentrations of cortisone (which circulates largely unbound at $\sim 100 \mathrm{nmol} / \mathrm{l}$ ) approximate or even exceed "free" cortisol levels, providing plentiful substrate for $11 \beta$ reductase (Walker et al., 1992). Similarly, levels of 11dehydrocorticosterone at $\sim 50 \mathrm{nmol} / \mathrm{l}$ are found in rat plasma ( $\mathrm{R}$. Best and J. R. Seckl, unpublished observations), concentrations well in excess of "free" corticosterone levels during the diurnal nadir. Such cell-specific activation of an inert circulating form is not unique to glucocorticoids and may be analogous to the activation of thyroxine to tri-iodothyronine by $5^{\prime}$-monodeiodinase and testosterone to dihydrotestosterone by $5 \alpha$-reductase in other tissues.

Why the activity of hippocampal $11 \beta$-reductase should increase with chronically elevated glucocorticoids also is unclear, because this seems to increase the neuron-jeopardizing effects of glucocorticoid excess. Perhaps the short- and medium-term metabolic and functional benefits of maximizing glucocorticoid exposure during stress outweigh any long-term detriments, particularly because potent negative feedback effects would be expected to rapidly attenuate glucocorticoid levels under most physiological circumstances. Further determination of the importance of hippocampal $11 \beta$-HSD activity will be assisted by the development of selective $11 \beta$-reductase inhibitors or transgenic animals lacking $11 \beta$-HSD1. Nevertheless, it is intriguing to spcculate that measures to attenuate hippocampal $11 \beta$-reductase may reduce neuronal vulnerability to glucocorticoid toxicity in a target-specific manner, analogous to the effects of long-term maintenance of more generalized low glucocorticoid levels by adrenalectomy (Landfield et al., 1978) or increasing sensitivity to glucocorticoid negative feedback (Sapolsky et al., 1984; Meaney et al., 1988, 1993; Seckl and Olsson, 1995).

\section{REFERENCES}

Agarwal AK, Monder C, Eckstein B, White PC (1989) Cloning and cxpression of rat cDNA encoding corticosteroid 11-dchydrogenasc. $\mathrm{J}$ Biol Chem 264:18939-18943.

Agarwal AK, Tusie-Luna M-T, Monder C, White PC (1990) Expression of $11 \beta$-hydroxysteroid dehydrogenase using recombinant vaccinia virus. Mol Endocrinol 4:1827-1832.

Albiston AL, Obeyesekere VR, Smith RE, Krozowski ZS (1994) Cloning and tissue distribution of the human $11 \beta$-hydroxysteroid dehydrogenase type 2 enzyme. Mol Cell Endocrinol 105:R11-R17.

Armanini D, Karbowiak I, Funder JW (1983) Affinity of liquorice derivatives for mineralocorticoid and glucocorticoid receptors. Clin Endocrinol 19:609-612.

Arriza JL, Simerly RB, Swanson LW, Evans RM (1988) The neuronal mineralocorticoid receptor as a mediator of glucocorticoid response. Neuron 1:887-900.

Arriza JL, Weinberger C, Cerelli G, Glaser TM, Handelin BL, Housman DE, Evans RM (1987) Cloning of human mineralocorticoid receptor 
complementary DNA: structural and functional kinship with the glucocorticoid receptor. Science 237:268-275.

Brown RW, Chapman KE, Edwards CRW, Seckl JR (1993) Human placental 11 $\beta$-hydroxysteroid dehydrogenase: partial purification of and cvidence for a distinct NAD-dependent isoform. Endocrinology 132:2614-2621.

Burton AF, Tufnell RW (1967) 11-Dehydrocorticosteroids in tissues of mice. Can J Biochem 46:497-502.

Chomczynski P, Sacchi N (1987) Single step method of RNA isolation by guanidium-thiocyanate-phenol-chloroform extraction. Anal Biochem 162:146-149.

de Kloet ER (1991) Brain corticosteroid receptor balance and homeostatic control. Front Neuroendocrinol 12:95-164.

de Kloet ER, Versteeg DHG, Kovacs GL (1983) Aldosterone blocks the response to corticosterone in the raphe-hippocampal serotonin system. Brain Res 264:323-327.

de Kloet ER, Wallach G, McEwen BS (1975) Differences in corticosterone and dexamethasone binding to rat brain and pituitary. Endocrinology 96:598-609.

Duperrex H, Kenouch S, Gaeggeler H-P, Seckl JR, Edwards CRW, Farman N, Rossier BC (1993) Rat liver 11 $\beta$-hydroxysteroid dehydrogenase cDNA encodes oxoreductase activity in a mineralocorticoidresponsive toad bladder cell line. Endocrinology 132:612-619.

Edwards CRW, Stewart PM, Burt D, Brett L, McIntyre MA, Sutanto WS, de Kloet ER, Monder C (1988) Localisation of $11 \beta$-hydroxysteroid dehydrogenase-tissue specific protector of the mineralocorticoid receptor. Lancet 2:986-989.

Funder JW, Pearce PT, Smith R, Smith AI (1988) Mineralocorticoid action: target tissue specificity is enzyme, not receptor, mediated. Science 242:583-585.

Gould E, Woolley CS, McEwen BS (1990) Short-term glucocorticoid manipulations affect neuronal morphology and survival in the adult dentate gyrus. Neuroscience 37:367-375.

Jamieson PM, Chapman KE, Edwards CRW, Seckl JR (1995) 11ß-Hydroxysteroid dehydrogenase is an exclusive $11 \beta$-reductase in primary rat hepatocyte cultures: effect of physicochemical and hormonal manipulations. Endocrinology, in press.

Lakshmi V, Monder C (1988) Purification and characterisation of the corticosteroid $11 \beta$-dehydrogenase component of the rat liver $11 \beta$-hydroxysteroid dehydrogenase complex. Endocrinology 123:2390-2398.

I akshmi V, Sakai RR, McEwen BS, Monder C (1991) Regional distribution of $11 \beta$-hydroxysteroid dehydrogenase in rat brain. Endocrinology 128:1741-1748.

Landfield PW, Eldridge JC (1991) The glucocorticoid hypothesis of brain aging and neurodegeneration: recent modifications. Acta Endocrinol 125:54-64.

Landfield PW, Waymire J, Lynch G (1978) Hippocampal aging and adrenocorticoids: a quantitative correlation. Science 202:1098-1102.

Low SC, Chapman KE, Edwards CRW, Seckl JR (1994a) Liver-type $11 \beta$-hydroxysteroid dehydrogenase cDNA encodes reductase not dehydrogenase activity in intact mammalian COS-7 cells. J Mol Endocrinol 13:167-174

Low SC, Moisan M-P, Edwards CRW, Seckl JR (1994b) Glucocorticoids and chronic stress up-regulate $11 \beta$-hydroxysteroid dehydrogenase activity and gene expression in the hippocampus. J Neuroendocrinol $6: 285-290$

McEwen BS, de Kloet ER, Rostene W (1986a) Adrenal steroid receptors and action in the ncrvous systcm. Physiol Rev 66:1121-1188.

McEwen BS, Lambdin LT, Rainbow TC, De Nicola AF (1986b) Aldosterone effects on salt appetite in adrenalectomised rats. Neuroendocrinology 43:38-43.

Meaney MJ, Aitken DH, van Berkel C, Bhatnagar S, Sapolsky RM (1988) Effect of neonatal handling on age-related impairments associated with the hippocampus. Science 239:766-768.

Meaney MJ, Bodnoff SR, O'Donnell D, Sarrieau A, Nair NPV, Diamond DM, Rose GM, Poirier J, Seckl JR (1993) Adrenal glucocorticoids as modulators of hippocampal neuron survival, repair and function in the aged rat. In: Restorative neurology (Cuello C, ed), pp 267-289. New York: Elsevier

Mitchell JB, Rowe W, Boksa P, Meaney MJ (1990) Serotonin regulates Type II corticosteroid receptor binding in hippocampal cell cultures. $\mathbf{J}$ Neurosci 10:1745-1752

Moisan M-P, Edwards CRW, Seckl JR (1992) Differential promoter usage by the rat $11 \beta$-hydroxysteroid dehydrogenase gene. Mol Endocrinol $6: 1082-1087$
Moisan M-P, Seckl JR, Edwards CRW (1990) 11ß-Hydroxysteroid dehydrogenase bioactivity and messenger RNA expression in rat forebrain: localization in hypothalamus, hippocampus and cortex. Endocrinology 127:1450-1455

Monder C (1991) Corticosteroids, receplors, and organ-specific functions of $11 \beta$-hydroxysteroid dehydrogenase. FASEB J 5:3047-3054.

Monder C, White PC (1993) 11 $\beta$-hydroxysteroid dehydrogenase. Vitam Horm 47:187-271.

Packan DR, Sapolsky RM (1990) Glucocorticoid endangerment of the hippocampus: tissue, steroid and receptor specificity. Neuroendocrinology 51:613-618.

Reul JMHM, de Kloet ER (1985) Two receptor systems for corticosterone in rat brain: microdissection and diffcrential occupation. Endocrinology 117:2505-2511.

Roland BL, Krozowski ZS, Funder JW (1995) Glucocorticoid receptor, mineralocorticoid receptor, $11 \beta$-hydroxysteroid dehydrogenase- 1 and -2 expression in rat brain and kidney: in situ studies. Mol Cell Endocrinol 111:R1-R5

Sakai RR, Lakshmi V, Monder C, McEwen BS (1992) Immunocytochemical localisation of $11 \beta$-hydroxysteroid dehydrogenase in hippocampus and other brain regions of the rat. $J$ Neuroendocrinol 4:101-106.

Sapolsky RM (1985) A mechanism for glucocorticoid toxicity in the hippocampus: increased neuronal vulnerability to metabolic insults. J Neurosci $5: 1228-1232$.

Sapolsky RM (1986) Glucocorticoid neurotoxicity in the hippocampus: synergy with kainic acid. Neuroendocrinology 43:386-391.

Sapolsky RM (1992) Stress, the aging brain and the mechanisms of neuron death. Cambridge, MA: MIT.

Sapolsky RM, Krey LC, McEwen BS (1985) Prolonged glucocorticoid exposure reduces hippocampal neuron number: implications for aging. J Ncurosci 5:1221-1226.

Sapolsky RM, Krey LC, McEwen BS (1986) The neuroendocrinology of stress and ageing. The glucocorticoid cascade hypothesis. Endocr Rev 7:284-301.

Sapolsky RM, Krey LC, McEwen BS, Rainbow TC (1984) Do vasopressin-related peptides induce hippocampal corticosteroid receptors? Implications for aging. $\mathbf{J}$ Neurosci $4: 1479-1485$.

Seckl JR (1993) 11ß-Hydroxysteroid dehydrogenase isoforms and their implications for blood pressure regulation. Eur $\mathbf{J}$ Clin Invest 23:589-601.

Seckl JR, Brown RW, Rajan V, Low SC, Edwards CRW (1993) $11 \beta$ Hydroxysteroid dehydrogenase and corticosteroid actions in the brain. J Endocrinol 137[Suppl]:S9.

Seckl JR, Kelly PAT, Sharkey J (1991) Glycyrrhetinic acid, an inhibitor of $11 \beta$-hydroxysteroid dehydrogenase, alters local cerebral glucose utilization in vivo. J Steroid Biochem Mol Biol 39:777-779.

Seckl JR, Olsson T (1995) Glucocorticoids and the age-impaired hippocampus: cause or effect? J Endocrinol 145:201-211.

Sloviter RS, Valiquette G, Abrams GM, Ronk EC, Sollas AL, Paul LA, Ncubort S (1989) Sclective loss of hippocampal granulc cells in the mature rat brain after adrenalectomy. Science 243:535-538.

Stewart PM, Corrie JET, Shackleton CHL, Edwards CW (1988) Syndrome of apparent mineralocorticoid excess: a defect in the cortisolcortisone shuttle. J Clin Invest 82:340-349.

Stewart PM, Valentino R, Wallace AM, Burt D, Shackleton CHL, Edwards CRW (1987) Mineralocorticoid activity of liquorice: $11 \beta$-hydroxysteroid dehydrogenase deficiency comes of age. Lancet 2:821-824

Stewart PM, Wallace AM, Atherden SM, Shearing CH, Edwards CRW (1990) Mineralocorticoid activity of carbenoxolone: contrasting effects of carbenoxolone and liquorice on $11 \beta$-hydroxysteroid dehydrogenase activity in man. Clin Sci 78:49-54.

Ulmann A, Menard J, Corvol P (1975) Binding of glycerrhetinic acid to kidney mineralocorticoid and glucocorticoid receptors. Endocrinology 97:46-51.

Walker BR, Campbell JC, Fraser R, Stewart PM, Edwards CRW (1992) Mineralocorticoid excess and inhibition of $11 \beta$-hydroxysteroid dehydrogenase in patients with ectopic ACTH syndrome. Clin Endocrinol 37:483-492.

Zhou M-Y, Gomez-Sanchez EP, Cosby D, Gomez-Sanchez CE (1995) Cloning of a NAD+-dependent $11 \beta$-hydroxysteroid dehydrogenase from rat kidney. 77th Annual Meeting of The Endocrine Society, Abstract P2-489. 